\title{
Anticancer effect of lysine, proline, arginine, ascorbic acid and green tea extract on human renal adenocarcinoma line 786-0
}

\author{
M. WAHEED ROOMI, VADIM IVANOV, TATIANA KALINOVSKY, \\ ALEKSANDRA NIEDZWIECKI and MATTHIAS RATH
}

\author{
Matthias Rath Research Institute, Cancer Division, 1260 Memorex Drive, Santa Clara, CA 95050, USA
}

Received May 9, 2006; Accepted July 19, 2006

\begin{abstract}
Five-year survival is limited to $60 \%$ in renal cancer patients at diagnosis. Due to the cancer's resistance to conventional treatments and associated high morbidity, we investigated the antimetastatic effects of a specific nutrient mixture (NM) containing lysine, proline, arginine, ascorbic acid and green tea extract on human renal adenocarcinoma cell line 786-0 by measuring: cell proliferation, modulation of MMP-2 and -9 secretion, and cancer cell invasive potential. Human renal cancer cell line 786-0 (ATCC) was grown in RPMI medium in 24-well tissue culture plates. At near confluence, the cells were treated with $\mathrm{NM}$, dissolved in media, and tested at 0,10 , $50,100,500$ and $1000 \mu \mathrm{g} / \mathrm{ml}$ in triplicate at each dose. Cells were also treated with PMA $200 \mathrm{ng} / \mathrm{ml}$ to study enhanced MMP-9 activity. Cell proliferation was evaluated by MTT assay, MMP secretion by gelatinase zymography, and invasion through Matrigel. Zymography demonstrated MMP-2 and MMP-9 secretion by uninduced renal cancer cells with enhanced MMP-9 induced by PMA $(200 \mathrm{ng} / \mathrm{ml})$ treatment. NM inhibited the secretion of both MMPs in a dose-dependent fashion with virtual total inhibition of MMP-2 at $500-\mu \mathrm{g} / \mathrm{ml}$ concentration and MMP-9 at $100 \mu \mathrm{g} / \mathrm{ml}$. The invasion of renal cancer cells through Matrigel was totally inhibited $(\mathrm{p}=0.0001)$ by $\mathrm{NM}$ at $1000 \mu \mathrm{g} / \mathrm{ml}$ concentration. Our results support a potential role for the nutrient mixture tested in the treatment of renal cell carcinoma, by inhibition of MMP-2 and MMP-9 secretion and invasion.
\end{abstract}

\section{Introduction}

The American Cancer Society estimates approximately 36,160 new cases of kidney cancer in 2005. Upon diagnosis, renal cell carcinoma is localized to the kidney in $50 \%$ of the cases, in another $25 \%$, the cancer will have spread to nearby

Correspondence to: Dr Aleksandra Niedzwiecki, Matthias Rath Research Institute, Cancer Division, 1260 Memorex Drive, Santa Clara, CA 95050, USA

E-mail: author@drrath.com

Key words: renal cancer, MMP-2, MMP-9, nutrient mixture, green tea extract, lysine, proline, arginine, ascorbic acid tissue, and in the remaining $25 \%$ will have metastasized to distant sites; associated 5-year survival in these patient groups is roughly 90,60 and 9\%, respectively (1). Late diagnosis is largely due to diverse clinical manifestations mistaken as symptoms of non-cancerous disease; symptoms may include hematuria, fatigue, edema, fever and weight loss and generally do not present in the early stages where conventional management of the cancer is most effective $(2,3)$.

Renal cell carcinoma (RCC) is erratic and unpredictable even when diagnosed and treated early by nephrectomy, as the neoplasm can appear to remain stable for years and then metastasize to distant locations (4). This anomaly may be epidemiological or may be due to the elimination of endostatin and angiostatin levels that prevent angiogenesis from occurring and the resulting proliferation of metastatic lesions to distant locations such as the lungs and lymph nodes (5). Traditional therapeutic approaches to RCC such as surgery, radiation therapy, chemotherapy and hormone therapy have largely been unsuccessful at controlling the progression of cancer (6-8). These methods do not address metastases and can promote tumor progression by impairing the immune system. Treatment methods focused on the regulation of tumor proliferation are necessary to effectively control RCC.

Abnormal expression of the family of zinc-dependant endopeptidases, known as matrix metalloproteinases (MMPs) can trigger degradation of the extracellular matrix (ECM), and underlying basal membranes that function as a barrier against cell migration, ultimately leading to tumoral progression. The role of MMPs on the progression of various malignancies has been reported in numerous studies (9-11). Furthermore, studies have found that MMP activity correlates with the invasiveness of the cancer.

Urokinase-type (uPA) and tissue-type (tPA) plasminogen activators that cleave plasminogen into active plasmin trigger MMP activity. In identifying the destruction of the ECM as a precondition for cancer cell invasion, growth and metastasis, Rath and Pauling proposed intervention of plasmin-induced proteolysis through such natural inhibitors, such as lysine and its analogues (12). Our previous studies have shown significant antitumoral activity of the nutrient combination (NM) tested against a number of cancer cell lines by inhibiting growth of the cancer cells, blocking tissue invasion and MMP secretion in vitro (13-15) and in vivo (16-18).

In the current study, we investigated a specific nutrient combination containing lysine, proline, arginine, ascorbic acid and green tea extract on human renal adenocarcinoma cell 
line $786-0$ by measuring cell proliferation, modulation of MMP-2 and -9 secretion, and cancer cell invasive potential.

\section{Materials and methods}

Cell culture. Human renal adenocarcinoma 786-0 cells [obtained from ATCC (American Type Culture Collection, Rockville, MD)] were grown in RPMI medium supplemented with $10 \%$ fetal bovine serum, penicillin $(100 \mathrm{U} / \mathrm{ml})$ and streptomycin $(100 \mathrm{mg} / \mathrm{ml})$ in 24-well tissue culture plates (Costar, Cambridge, MA). Cells were incubated with $1 \mathrm{ml}$ of media at $37^{\circ} \mathrm{C}$ in a tissue culture incubator equilibrated with $95 \%$ air and $5 \% \mathrm{CO}_{2}$. At near confluence, the cells were treated with NM dissolved in media and tested at 0, 10, 50, 100, 500 and $1000 \mu \mathrm{g} / \mathrm{ml}$ in triplicate at each dose. Cells were also treated with PMA $200 \mathrm{ng} / \mathrm{ml}$ to study enhanced MMP-9 expression. The plates were then returned to the incubator.

MTT assay. Cell proliferation was evaluated by MTT assay, a colorimetric assay based on the ability of viable cells to reduce a soluble yellow tetrazolium salt [3-(4,5-dimethylthiazol-2-yl) 2,5-diphenyl tetrazolium bromide] (MTT) to a blue formazan crystal by mitochondrial succinate dehydrogenase activity of viable cells. This test is a good index of mitochondrial activity and thus of cell viability. After $24 \mathrm{~h}$ incubation, the cells were washed with phosphate-buffered saline (PBS) and $500 \mu \mathrm{l}$ of MTT (Sigma \#M-2128) $0.5 \mathrm{mg} / \mathrm{ml}$ in media was added to each well. After MTT addition $(0.5 \mathrm{mg} / \mathrm{ml})$, the plates were covered and returned to the $37^{\circ} \mathrm{C}$ incubator for $2 \mathrm{~h}$, the optimal time for formazan product formation. Following incubation, the supernatant was carefully removed from the wells, the formazan product was dissolved in $1 \mathrm{ml} \mathrm{DMSO}$, and absorbance was measured at $570 \mathrm{~nm}$ in a Bio Spec 1601, Shimadzu spectrometer. The $\mathrm{OD}_{570}$ of the DMSO solution in each well was considered to be proportional to the number of cells. The $\mathrm{OD}_{570}$ of the control (treatment without supplement) was considered to be $100 \%$.

Gelatinase zymography. MMP secretion in conditioned media was determined by gelatinase zymography. Gelatinase zymography was performed in $10 \%$ polyacrylamide precast Novex gel (Invitrogen Corp.) in the presence of $0.1 \%$ gelatin. Culture media $(20 \mu \mathrm{l})$ was loaded and SDS-PAGE was performed with a Tris-glycine SDS buffer. After electrophoresis, the gels were washed with $5 \%$ Triton $\mathrm{X}-100$ for $30 \mathrm{~min}$. The gels were then incubated for $24 \mathrm{~h}$ at $37^{\circ} \mathrm{C}$ in the presence of $50 \mathrm{mM}$ Tris- $\mathrm{HCl}, 5 \mathrm{mM} \mathrm{CaCl}_{2}, 5 \mu \mathrm{M} \mathrm{ZnCl}_{2}$, pH 7.5 and stained with Coomassie Blue R $0.5 \%$ for $30 \mathrm{~min}$ and destained. Protein standards were run concurrently and approximate molecular weights were determined.

Matrigel invasion studies. Invasion studies were conducted using Matrigel (Becton-Dickinson) inserts in 24-well plates. Suspended in medium, human renal adenocarcinoma 786-0 cells were supplemented with nutrients, as specified in the design of the experiment and seeded on the insert in the well. Thus both the medium on the insert and in the well contained the same supplements. The plates with the inserts were then incubated in a culture incubator equilibrated with $95 \%$ air and
$5 \% \mathrm{CO}_{2}$ for $24 \mathrm{~h}$. After incubation, the media from the wells were withdrawn. The cells on the upper surface of the inserts were gently scrubbed away with cotton swabs. The cells that had penetrated the Matrigel membrane and migrated onto the lower surface of the Matrigel were stained with hematoxylin and eosin and visually counted under the microscope.

Morphology. Morphology of cells cultured for $24 \mathrm{~h}$ in test concentrations of NM were evaluated by H\&E staining and observed and photographed by microscopy.

Composition of the nutrient mixture (NM). The composition of the nutrient mixture used for testing was composed of the following in the ratios indicated: vitamin $\mathrm{C}$ (as ascorbic acid and as $\mathrm{Mg}$, Ca, and palmitoyl ascorbate) $700 \mathrm{mg}$; L-lysine $1000 \mathrm{mg}$; L-proline $750 \mathrm{mg}$; L-arginine $500 \mathrm{mg}$; N-acetyl cysteine $200 \mathrm{mg}$; and standardized green tea extract $1000 \mathrm{mg}$ (green tea extract derived from green tea leaves was obtained from US Pharma Lab). The certificate of analysis indicates the following characteristics: total polyphenol $80 \%$, catechins $60 \%$, epigallocatechin gallate (EGCG) $35 \%$, and caffeine $1.0 \%$ ); selenium $30 \mu \mathrm{g}$; copper $2 \mathrm{mg}$; and manganese $1 \mathrm{mg}$.

The nutrient mixture (NM) was formulated based on targeting different physiological processes involved in cancer progression and metastasis. For example, the ECM integrity is dependent upon adequate collagen formation and its stability. In this aspect ascorbic acid and the amino acids lysine and proline are necessary for the formation and optimum structure of collagen fibers. Manganese and copper are also essential cofactors in collagen formation process. Collagen stability can be controlled by lysine (12) and also by $\mathrm{N}$-acetyl cysteine through its inhibitory effect on MMP-9 activity (19) and invasive activities of tumor cells (20). Also, selenium has been shown to interfere with MMP expression and tumor invasion (21), as well as migration of endothelial cells through ECM (20). Ascorbic acid has been shown to inhibit cell division and growth through production of hydrogen peroxide (22). Green tea extract has been shown to be a promising agent in controlling angiogenesis, metastasis, and other aspects of cancer progression (23). Since arginine is a precursor of nitric oxide (NO), any deficiency of arginine can limit the production of NO, which has been shown to predominantly act as an inducer of apoptosis, as in the case of breast cancer cells (24).

Based on the evidence available in literature and our own research, we have postulated that metabolic effects of a combination of ascorbic acid, lysine, proline, green tea extract, arginine, $\mathrm{N}$-acetyl cysteine, selenium, copper and manganese would result from their synergy. For example, we found that a combination of ascorbic acid, lysine and proline used with EGCG enhanced the anti-invasive activity of $20 \mu \mathrm{g} / \mathrm{ml}$ EGCG to that of $50 \mu \mathrm{g} / \mathrm{ml}$ (25). Thus by including nutrients like $\mathrm{N}$-acetyl cysteine, arginine, selenium, manganese and copper in addition to ascorbic acid, proline, lysine and EGCG we could obtain significant reduction in cell invasion at a much lower concentration of EGCG.

Statistical analysis. The results were expressed as means \pm SD for the groups. Data were analyzed by independent sample t-test. 


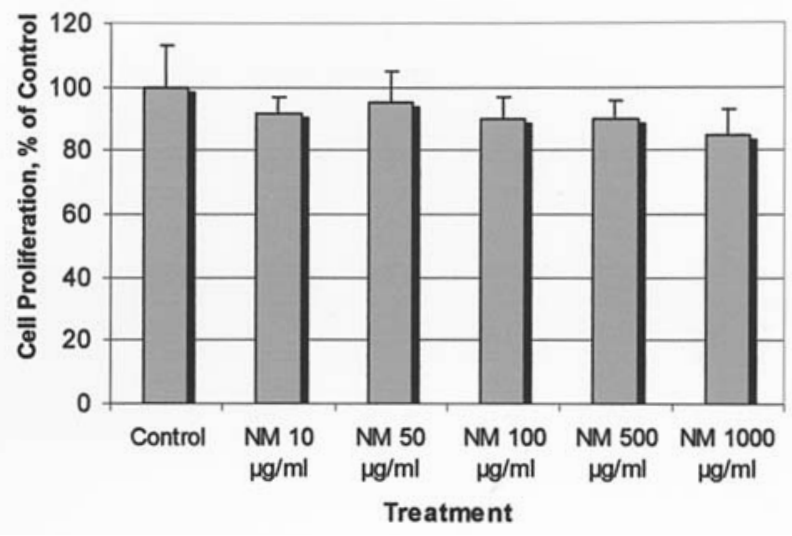

Figure 1. Effect of the nutrient mixture (NM) on growth of human renal cancer cell line 786-0: $24 \mathrm{~h}$ MTT assay. NM showed no significant effect on renal cancer cell growth.

\section{Results}

Cell proliferation study. The nutrient mixture (NM) showed no significant effect on renal cancer cell growth (Fig. 1).

Gelatinaze zymography study. Zymography demonstrated MMP-2 and MMP-9 secretion by uninduced human renal cancer cells (Fig. 2A) with enhanced MMP-9 secretion by PMA (200 ng/ml)-treated cells (Fig. 2B). NM inhibited the secretion of both MMPs in a dose-dependent fashion with virtual total inhibition of MMP-2 at $500 \mu \mathrm{g} / \mathrm{ml}$ concentration and MMP-9 at $100 \mu \mathrm{g} / \mathrm{ml}$.

Matrigel invasion study. The invasion of human renal cancer cells through Matrigel was significantly reduced at $500 \mu \mathrm{g} /$ $\mathrm{ml}$ (by $82 \%, \mathrm{p}=0.0003)$ and totally inhibited $(\mathrm{p}=0.0001)$ at $1000 \mu \mathrm{g} / \mathrm{ml}$ concentration of NM (Fig. 3).

Morphology study (hematoxylin and eosin staining). H\&E staining showed no morphological changes at the tested doses of NM (Fig. 4).

\section{Discussion}

Numerous studies have documented a correlation between increased MMP-2 and MMP-9 activity and poor survival in a

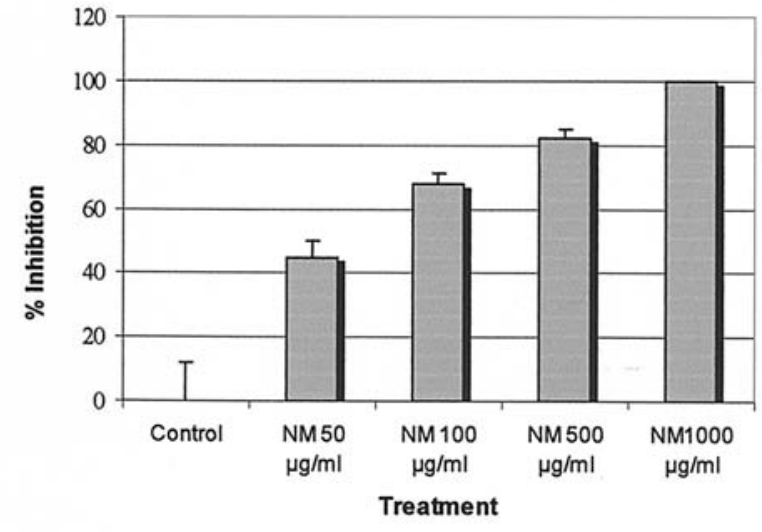

Figure 3. Effect of the nutrient mixture (NM) on human renal cancer cell 786-0 Matrigel invasion. The invasion of human renal cancer cells through Matrigel was significantly reduced at $500 \mu \mathrm{g} / \mathrm{ml}$ (by $82 \%, \mathrm{p}=0.0003$ ) and totally inhibited ( $\mathrm{p}=0.0001)$ at $1000 \mu \mathrm{g} / \mathrm{ml}$ concentration of NM.

number of malignancies, including renal cell carcinoma (26) In vitro, it has been found that highly metastatic cells secrete more MMPs than do poorly metastatic cells (27). In vivo, studies have also documented that transgenic mice associated with overexpression of MMPs develop more cancers than do control mice (28). This data has prompted researchers to investigate the efficacy of new treatment methods that target universal pathomechanisms involved in caner progression, such as control of proteolytic activity of the ECM.

Rath and Pauling have suggested targeting plasminmediated mechanisms with lysine and lysine analogues (12). Metastatic spread to remote sites is dependant upon the ability of the tumor to penetrate the basement membrane and extracellular matrix. Matrix invasion can be prevented by strengthening the connective tissue surrounding the cancer cells, contributing to the 'encapsulation' the tumor. Optimization of synthesis and structure of collagen fibrils depends on hydroxylation of proline and lysine residues in collagen fibrils. Adequate levels of ascorbic acid are essential for the hydroxylation of proline and lysine. Additionally, lysine prevents collagen-digesting enzymes from binding to plasminogen active sites, blocking the activation of plasmin by plasminogen, thereby preventing cell migration.

While the mechanistic action of the nutrients tested was not reviewed in the scope of this experiment, the dose-dependant
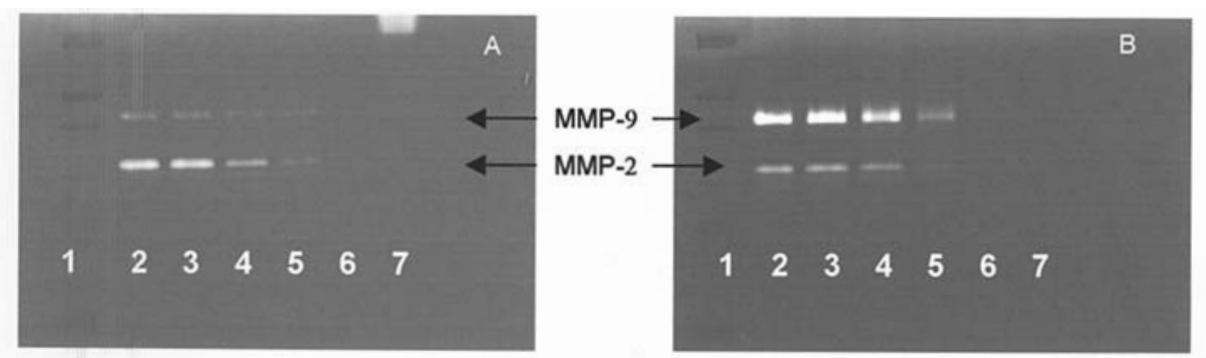

Figure 2. Effect of the nutrient mixture (NM) on MMP-2 and MMP-9 secretion by human renal cancer 786-0 cells: (A), Untreated cells; (B), PMA (200 ng/ $\mathrm{ml}$ )-treated cells. Legend 1, markers; 2-Control, 3-7 NM 10, 50, 100, 500, $1000 \mu \mathrm{g} / \mathrm{ml}$. Zymography demonstrated MMP-2 and MMP-9 secretion by uninduced human renal cancer cells and enhanced MMP-9 secretion by PMA-treated cells. NM inhibited the secretion of both MMPs in a dose-dependent fashion with virtual total inhibition of MMP-2 at $500 \mu \mathrm{g} / \mathrm{ml}$ concentration and MMP-9 at $100 \mu \mathrm{g} / \mathrm{ml}$. 

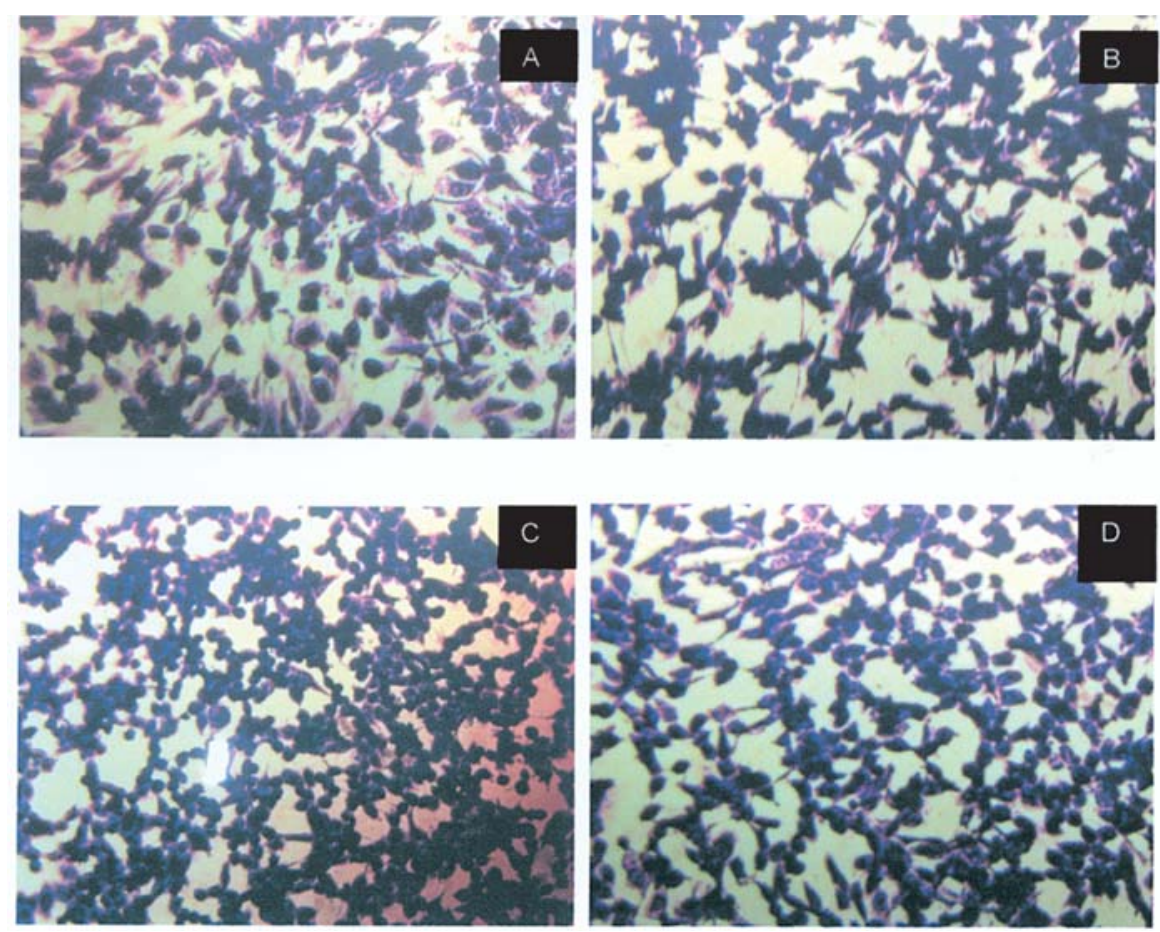

Figure 4. Effect of NM on human renal cancer cell 786-0 morphology (H\&E staining): (A), Control; (B), NM $50 \mu \mathrm{g} / \mathrm{ml}$; (C), $100 \mu \mathrm{g} / \mathrm{ml}$; (D), $1000 \mu \mathrm{g} / \mathrm{ml}$.

inhibitory effect of the nutrient mixture on MMP-2 and MMP-9 secretion by human renal adenocarcinoma cell line 786-0 was consistent with its dose-dependent inhibition of matrix invasion, suggesting that the nutrients tested enhanced the stability of the connective tissue, as lysine, proline, ascorbic acid, manganese and copper support collagen formation. Complete inhibition of invasion of renal cancer cells was seen at $1000 \mu \mathrm{g} / \mathrm{ml}$ concentration NM ( $\mathrm{p}=0.0001)$. The nutrient mixture inhibited MMP-2 and MMP-9 secretion in a dose-dependent fashion with virtual total inhibition of MMP-2 at $500 \mu \mathrm{g} / \mathrm{ml} \mathrm{NM}$ concentration and MMP-9 at $100 \mu \mathrm{g} / \mathrm{ml}$, demonstrating potent antimetastatic action.

The inhibitory effects of the individual nutrients tested have been reported in both clinical and experimental studies. Ascorbic acid has been reported to exert cytotoxic and antimetastatic actions on malignant cell lines (29-31); in addition, low levels of ascorbic acid have been reported in cancer patients (32-34). In another study, tumor cell invasion of a reconstituted basement membrane matrix was reduced by $50 \%$ with epigallocatechin-3-gallate (EGCG) concentrations equivalent to that in the plasma of moderate green tea drinkers, and 2 orders of magnitude below those of tissue inhibitors of MMPs, demonstrating potent antiangiogenic and antimetastatic potential (35). However, our previous studies indicated that the inhibitory effect of ascorbic acid, proline, lysine and EGCG on several cancer cell lines in tissue culture studies was greater than that of the individual nutrients (25). Furthermore, in contrast to chemotherapy, which causes indiscriminate cellular and ECM damage, morphological studies showed that even at the highest concentrations of NM, renal cancer cells were not affected, demonstrating that this formulation is non-toxic to cells.

By inhibition of MMP-2 and MMP-9 secretion and invasion, our results suggest that the mixture of lysine, proline, ascorbic acid and green tea extract studied is an excellent candidate for preventative and therapeutic use in the treatment of renal cancer; however, additional studies on animal models and clinical trials are necessary to more fully evaluate the role of nutrient supplementation in the treatment of cancer.

\section{References}

1. American Cancer Society: Cancer Facts and Figures 2005 Atlanta, GA: American Cancer Society, 2005.

2. Motzer RJ: Renal cell carcinoma: a priority malignancy for development and study of novel therapies. J Clin Oncol 21: 1193-1194, 2003

3. Bui MH, Zisman A, Pantuck AJ, Han KR, Wieder J and Belldegrun AS: Prognostic factors and molecular markers for renal cell carcinoma. Expert Rev Anticancer Ther 1: 565-575, 2001.

4. Chae EJ, Kim JK, Kim SH, Bae SJ and Cho KS: Renal cell carcinoma: analysis of post-operative recurrence patterns. Radiology 234: 189-196, 2005.

5. Peeters CF, De Geus LF, Westphal JR, et al: Decrease in circulating anti-angiogenic factors (angiostatin and endostatin) after surgical removal of primary colorectal carcinoma coincides with increased metabolic activity of liver metastases. Surgery 137: 246-249, 2005.

6. Scharovsky OG, Binda MM, Rozados VR, Bhagat S, Cher ML and Bonfil RD: Angiogenic and antiangiogenic balance regulates concomitant antitumoral resistance. Clin Exp Metastasis 21: $177-183,2004$

7. Wolchok JD and Motzer RJ: Management of renal cell carcinoma. Oncology 14: 29-36, 2000.

8. Motzer RJ, Mazumdar M, Bacik J, Berg W, Amsterdam A and Ferrara J: Survival and prognostic stratification of 670 patients with advanced renal cell carcinoma. J Clin Oncol 17: 2530-2540, 1999.

9. Curran S and Murray GI: Matrix metalloproteinases in tumour invasion and metastasis. J Pathol 189: 300-308, 1999.

10. Lein M, Jung K, Laube C, et al: Matrix-metalloproteinases and their inhibitors in plasma and tumor tissue of patients with renal cell carcinoma. Int J Cancer 85: 801-804, 2000.

11. Kamiya N, Kishimoto T, Suzuki H, et al: Increased in situ gelatinolytic activity in renal cell tumor tissues correlates with tumor size, grade and vessel invasion. Int J Cancer 106: 480-485, 2003. 
12. Rath M and Pauling L: Plasmin-induced proteolysis and the role of apoprotein(a), lysine and synthetic analogs. Orthomol Med 7: 17-23, 1992.

13. Netke SP, Roomi MW, Ivanov V, Niedzwiecki A and Rath M: A specific combination of ascorbic acid, lysine, proline and green tea extract inhibits proliferation and extracellular matrix invasion of various human cancer cell lines. Research communications in pharmacology and toxicology: Emerging Drugs 2: 37-50, 2003.

14. Roomi MW, Ivanov V, Kalinovsky T, Niedzwiecki A and Rath M: Antitumor effect of nutrient synergy on human osteosarcoma cells U-2OS, MNNG-HOS and Ewing's sarcoma SK-ES.1. Oncol Rep 13: 253-257, 2005.

15. Roomi MW, Ivanov V, Kalinovsky T, Niedzwiecki A and Rath M: Synergistic effect of combination of lysine, proline, arginine, ascorbic acid and epigallocatechin gallate on colon cancer cell line HCT 116. JANA 7: 40-43, 2004.

16. Roomi MW, Ivanov V, Kalinovsky T, Niedzwiecki A and Rath M: In vivo antitumor effect of ascorbic acid, lysine, proline and green tea extract on human colon cancer cell HCT 116 xenografts in nude mice: evaluation of tumor growth and immunohistochemistry. Oncol Rep 13: 421-425, 2005.

17. Roomi MW, Ivanov V, Kalinovsky T, Niedzwiecki A and Rath M: In vivo antitumor effect of ascorbic acid, lysine, proline and green tea extract on human prostate cancer PC-3 xenografts in nude mice: evaluation of tumor growth and immunohistochemistry. In vivo 19: 179-183, 2005.

18. Roomi MW, Ivanov V, Kalinovsky T, Niedzwiecki A and Rath M: Modulation of N-methyl-N-nitrosourea induced mammary tumors in Sprague-Dawley rats by combination of lysine, proline, arginine, ascorbic acid and green tea extract. Breast Cancer Res 7: R291-R295, 2005.

19. Kawakami S, Kageyama Y, Fujii Y, et al: Inhibitory effects of $\mathrm{N}$-acetyl cysteine on invasion and MMP 9 production of T24 human bladder cancer cells. Anticancer Res 21: 213-219, 2001 .

20. Morini M, Cai T, Aluigi MG, et al: The role of the thiol Nacetyl cysteine in the prevention of tumor invasion and angiogenesis. Int J Biol Markers 14: 268-271, 1999.

21. Yoon SO, Kim MM and Chung AS: Inhibitory effects of selenite on invasion of HT 1080 tumor cells. J Biol Chem 276 20085-20092, 2001.

22. Chen Q, Espey MG, Krishna MC, et al: Pharmacologic ascorbic acid concentrations selectively kill cancer cells: action as a prodrug to deliver hydrogen peroxide to tissues. Proc Natl Acad Sci USA 102: 13604-13609, 2005.
23. Hare Y: Green tea: Health Benefits and Applications. Marcel Dekker (ed). Basel, 2001

24. Cooke JP and Dzau VJ: Nitric oxide synthase: Role in the genesis of vascular disease. Annu Rev Med 48: 489-509, 1997.

25. Roomi MW, Ivanov V, Niedzwiecki A and Rath M: Synergistic antitumor effect of ascorbic acid, lysine, proline and epigallocatechin gallate on human fibrosarcoma cells HT-1080. Ann Cancer Res Ther 12: 1-2, 2004.

26. Kallakury BV, Karikehalli S, Haholu A, Sheehan CE, Azumi N and Ross JS: Increased expression of matrix metalloproteinases 2 and 9 and tissue inhibitors of metalloproteinases 1 and 2 correlate with poor prognostic variables in renal cell carcinoma. Clin Cancer Res 7: 3113-3119, 2001.

27. Foda HD and Zucker S: Matrix metalloproteinases in cancer invasion, metastasis and angiogenesis. Drug Discov Today 6: 478-482, 2001.

28. Ha HY, Moon HB, Nam MS, et al: Overexpression of membrane-type matrix metalloproteinase-1 gene induces mammary gland abnormalities and adenocarcinoma in transgenic mice. Cancer Res 61: 984-990, 2001

29. Naidu KA, Karl RC and Coppola D: Antiproliferative and proapoptotic effect of ascorbyl stearate in human pancreatic cancer cells: association with decreased expression of insulin-like growth factor 1 receptor. Dig Dis Sci 48: 230-237, 2003.

30. Anthony HM and Schorah CJ: Severe hypovitaminosis C in lung-cancer patients: the utilization of vitamin $\mathrm{C}$ in surgical repair and lymphocyte related host resistance. Br J Cancer 46 354-367, 1982.

31. Metz N, Lobstein A, Schneider Y, et al: Suppression of azoxymethane-induced preneoplastic lesions and inhibition of cyclooxygenase- 2 activity in the colonic mucosa of rats drinking a crude green tea extract. Nutr Cancer 38: 60-64, 2000

32. Koh WS, Lee SJ, Lee H, et al: Differential effects and transport kinetics of ascorbate derivatives in leukemic cell lines. Anticancer Res 8: 2487-2493, 1998.

33. Nunez C, Ortiz de Apodaca Y and Ruiz A: Ascorbic acid in the plasma and blood cells of women with breast cancer. The effect of consumption of food with an elevated content of this vitamin. Nutr Hosp 10: 368-372, 1995.

34. Kurbacher CM, Wagner U, Kolster B, et al: Ascorbic acid (vitamin C) improves the antineoplastic activity doxorubicin, cisplatin and paclitaxel in human breast carcinoma cells in vitro. Cancer Lett 103: 183-189, 1996

35. Garbisa S, Sartor L, Biggin S, Salvato B, Benelli R and Albini A Tumor gelatinases and invasion inhibited by the green tea flavanol epigallocatechin-3-gallate. Cancer 91: 822-832, 2001. 